\section{Icelandic Geothermal Activity and the Mercury of the Greenland Icecap}

A RECENT controversy over mercury found in Greenland ice cores $^{1-3}$ has served to underscore the need for more information about natural sources and modes of dissemination of the element.

Following the demonstration of high levels of atmospheric mercury in Hawaiian thermal areas ${ }^{4}$, similar aerometric studies were conducted at a number of sites in Iceland during June and July 1972. Field air sampling procedures and analyses by flameless atomic absorption were carried out as described in the Hawaiian study.

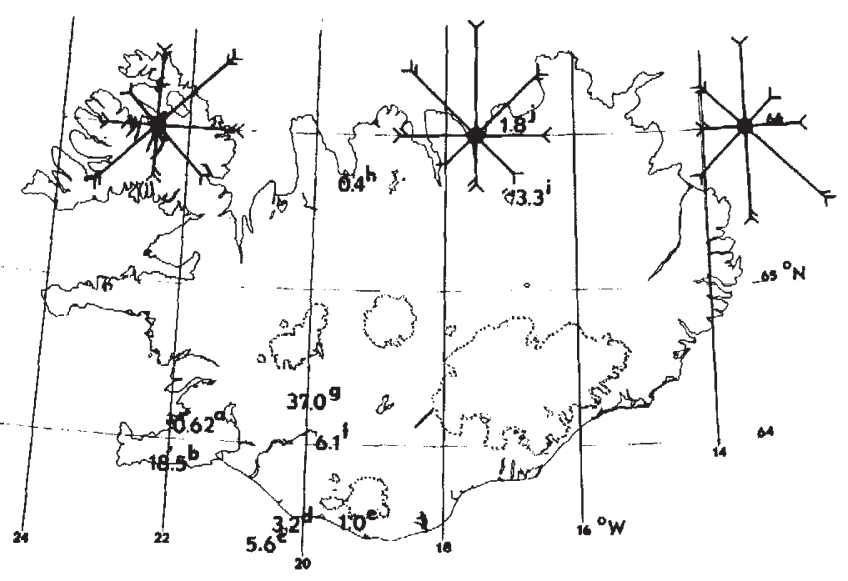

Fig. 1 Aerometry of mercury in Iceland. Located on the outline map are the atmospheric mercury levels (in $\mu \mathrm{g} \mathrm{m}^{-3}$ ) in June and July 1972, and representative wind vector ("windrose") patterns for June 1972. Mercury sampling sites were: a Reykjavík; b, Krýsuvik; c, Surtsey; d, Heimaey; e, Solheimajökull; f, Hekla; g, Geysir; h, Varmahlid; i, Myvatn; j, Húsavík.

Although atmospheric mercury levels vary greatly according to site, samples from several widely separated locations (Fig. 1) yielded $\mathrm{Hg}$ concentrations well above the range commonly cited for unpolluted $\mathrm{air}^{5}, 0.001-0.010 \mu \mathrm{g} \mathrm{m}^{-3}$. The general reliability of field measurements is indicated by samples taken at the Krýsuvik thermal area where duplicate analyses on each of four separate sample traps yielded a mean value of 11.3 $\mu \mathrm{g} \mathrm{m}^{-3}$ and a standard error of only $\pm 1.8 \mu \mathrm{g} \mathrm{m}^{-3}$. In the Westmann Islands (including Surtsey), five sites yielded a mean Hg level of $2.4 \pm 0.8 \mu \mathrm{g} \mathrm{m}^{-3}$.

Atmospheric mercury may be introduced in part by degassing of fluid magmas, but release from fine ash could also serve as a vehicle. Thus, an acid condensate from Surtsey yielded on analysis 350 p.p.b. $\mathrm{Hg}$ and tephrafines collected in the first two hours of the 1970 Hekla eruption contained 375 p.p.b. of readily water-soluble $\mathrm{Hg}$.

Long range transport of volcanic ejecta eastward from Iceland is well established. Thorarinsson ${ }^{6,7}$ notes that in 1947 , tephra was deposited in Finland, some $3,000 \mathrm{~km}$ distant, two days after Hekla began its great eruption; and that the vast gas emission accompanying the Lakagigar eruption of June 1783 caused a blue haze which spread for months over all of Iceland, most of Europe and proximal parts of Africa and Asia. Although these episodes show the feasibility of atmospheric transport, advection from Greenland to Iceland would be favoured by prevailing westerly winds. Examination of North Atlantic wind vector patterns ${ }^{8}$ (Fig. 1) show that the winds (in June, for example) may blow as much as $30-50 \%$ of the time from east to west across Iceland toward Greenland. Furthermore, North Atlantic gales, which are commonly associated with eastward moving cyclones, sustain a westward circulation in their northern sectors, and provide additional means for conveying effluents from Iceland to Greenland ${ }^{9}$.

The presence of substantial $\mathrm{Hg}$ levels in deep North Atlantic sediments located $\mathrm{S}, \mathrm{SW}$, and $\mathrm{W}$ of Iceland ${ }^{10}$ may also reflect long term transport and fallout of Icelandic mercury in nearby waters ${ }^{9}$.

Whatever may be the significance of time-variable mercury levels, they cannot be viewed as evidence for human input when it is recalled that from the mid-17th century to the present, Iceland has recorded nearly 50 volcanic eruptions including some of the greatest in the post-glacial history of the Earth.

We thank Dr Gudmundur E. Sigvaldason and the Division of Geosciences at the University of Iceland for generous laboratory facilities and cooperation in field collection and sampling. This work was supported in part by the National Aeronautics and Space Administration, the Cottrell Foundation of the Research Corporation, the University of Hawaii Foundation, and the University of Hawaii Environmental Center.

\section{B. Z. SiEgeL.}

Department of Microbiology,

University of Hawaii,

Honolulu, Hawaii 96822

S. M. SIEGEL

Department of Botany,

University of Hawaii

\section{F. THORARINSSON}

Division of Geosciences,

Science Institute,

University of Iceland,

Reykjavik

Received October 13.

1 Weiss, H. V., Koide, M., and Goldberg, E. D., Science, 174, 692 (1971).

2 Dickson, E. D., Science, 177, 536 (1972).

3 Patterson, C. C., Weiss, H..V., Koide, M., and Goldberg, E. D. Science, 177, 538 (1972).

${ }^{4}$ Eshleman, A., Siegel, S. M., and Siegel, B. Z., Nature, 233, 471 (1971).

5 McCarthy, J. H., Meuschke, L., Ficklin, W. H., and Learned, R. E., Prof. Pap. US Geol, Surv., No. 713, 37 (1970).

6 Thorarinsson, S., Natural History, 80, 58 (1971).

7 Thorarinsson, S., Bulletin Volcanologique, 33, 910 (1969).

8 US Naval Oceanographic Off., Pilot Chart of the North Atlantic, N.O. 16, June 1972 .

9 Pers. Comm., Price, S., Regional Climatologist, Pacific Region, US Dept. of Commerce, NOAA (1972).

10 Aston, S. R., Bruty, D., Chester, R., and Riley, J. P., Nature, 237, $125(1972)$

\section{Distribution of Dissolved Mercury in the Irish Sea}

Preston et al. ${ }^{1}$ have recently examined the distribution of a number of heavy metals in British coastal waters. They have found that the average concentrations of these elements in waters and marine organisms were significantly higher in samples from the eastern Irish Sea than in those from other areas. Fish and shellfish from this region (particularly the Mersey Estuary and Lune Deep) have been observed to have the highest average contents of mercury of any from around the British Isles ${ }^{2}$. No data are available for the concentration of the element in the seawater of the Irish Sea, nor is anything known about whether significant mercury pollution arises from liquid wastes discharged into the sea from the populous, highly industrialized areas of Lancashire. Trade effluents from 